\title{
ANALISIS YURIDIS PERTANGGUNGJAWABAN PIDANA TERHADAP KORPORASI ATAS PENGRUSAKAN HUTAN
}

\author{
Oleh: \\ Muhammad Ansori Lubis \\ Muhammad Siddiq \\ Universitas Darma Agung, Medan \\ Email: \\ ansoriboy67@gmail.com \\ siddiq@gmail.com
}

\begin{abstract}
Forests are a gift from God Almighty as a source of natural wealth that provides versatile benefits that are absolutely needed by mankind throughout the ages. The responsibility of corporations related to forest destruction criminal acts in Law Number 41 of 1999 is contained in Article 78 paragraph (14) which states that criminal acts as referred to in Article 50 if committed by and or on behalf of a legal entity or business entity, the prosecution and criminal sanctions shall be imposed the management, either individually or collectively, shall be subject to punishment in accordance with the respective penalties plus 1/3 (one third) of the sentence imposed ". Corporate responsibility in Law Number 41 of 1999 concerning Forestry.
\end{abstract}

Keywords: Forest Destruction, Criminal Liability, Corporation

\begin{abstract}
ABSTRAK
Hutan adalah karunia Tuhan Yang Maha Esa sebagai sumber kekayaan alam yang memberikan manfaat serbaguna yang mutlak dibutuhkan oleh umat manusia sepanjang masa. Pertanggungjawaban korporasi terkait dengan tindak pidana pengrusakan hutan dalam Undang Undang Nomor 41 Tahun 1999 terdapat pada Pasal 78 ayat (14) yang merumuskan bahwa Tindak pidana sebagaimana dimaksud Pasal 50 apabila dilakukan oleh dan atau atas nama badan hukum atau badan usaha, tuntutan dan sanksi pidananya dijatuhkan terhadap pengurusnya, baik sendirisendiri maupun bersama-sama, dikenakan pidana sesuai dengan ancaman pidana masing-masing ditambah dengan $1 / 3$ (sepertiga) dari pidana yang dijatuhkan". Tanggung jawab korporasi pada Undang-Undang Nomor 41 Tahun 1999 tentang Kehutanan.
\end{abstract}

Kata Kunci: Pengrusakan Hutan, Pertanggungjawaban Pidana, Korporasi

I. PENDAHULUAN

A. Latar Belakang

Sebagaimana dimaksud Pasal
50 apabila dilakukan oleh dan atau atas nama badan hukum atau badan usaha, tuntutan dan sanksi pidananya dijatuhkan terhadap pengurusnya, 
baik sendiri-sendiri maupun bersamasama, dikenakan pidana sesuai dengan ancaman pidana masingmasing ditambah dengan $1 / 3$ (sepertiga) dari pidana yang dijatuhkan". Tanggung jawab korporasi pada Undang-Undang Nomor 41 Tahun 1999 tentang Kehutanan, apabila tindak pidana yang dilakukan oleh dan atau atas nama badan hukum atau badan usaha, yang bertanggujawab adalah pengurusnya, baik sendiri-sendiri maupun bersama sama, ini maksudnya dapat ditafsirkan bahwa pengurus atas nama pribadi atau sendiri dapat diminta pertanggungjwaban atau pengurus yang melakukan secara bersamasama bisa diminta pertangggujawaban. Oleh karenanya bukan badan hukum yang bisa diminta pertanggujawaban dalam tindak pidana korporasi ini, hanya pada pengurus dari badan hukum yang bisa diminta pertanggungjwaban.

Bentuk-bentuk kejahatan korporasi dapat diklasifikasilan menjadi 3 (tiga) macam, yaitu:

a) Kejahatan korporasi dibidang ekonomi, antara lain berupa perbuatan tidak melaporkan keuntungan perusahaan yang sebenarnya, menghindari atau memperkecil pembayaran pajak dengan cara melaporkan data yang tidak sesuai dengan keadaan yang sebenarnya, persengkongloan dalam penentuan harga, memberikan sumbangan kampanye politik secara tidak sah.

b) Kejahatan korporasi dibidang sosial budaya, antara lain; kejahatan hak cipta, kejahatan terhadap buruh, kejahatan narkotika dan psikotropika; dan

c) Kejahatan korporasi yang menyangkut masyarakat luas. Hal ini dapat terjadi pada lingkungan hidup, konsumen dan pemegang saham.

\section{Perkembangan}

pertanggungjawaban pidana di Indonesia, ternyata yang dapat dipertanggungjawabkan tidak hanya manusia, tetapi juga korporasi. Khusus mengenai pertanggungjawaban korporasi dalam hukum pidana, ternyata terdapat bermacam-macam cara perumusannya yang ditempuh oleh pembuat undang undang. Ada 3 (tiga) sistem kedudukan korporasi dalam hukum pidana yakni:

1. Pengurus korporasi sebagai pembuat dan pengurus yang bertanggungjawab

2. Korporasi sebagai pembuat dan pengurus yang bertanggungjawab;

3. Korporasi sebagai pembuat dan yang bertanggunjawab.

Menurut Muladi, berkaitan dengan pertanggungjawaban korporasi dan memperhatikan dasar pengalaman pengaturan hukum positif serta pemikiran yang berkembang maupun kecendrungan internasional, maka pertanggungjawaban korporasi dalam tindak pidana lingkungan hendaknya memperhatikan hal-hal:

1. Korporasi mencakup baik badan hukum (legal entity) maupun non badan hukum seperti organisasi dan sebagainya;

2. Korporasi dapat bersifat privat (private juridical entity) dan dapat pula bersifat publik (public entity); 
3. Apabila diidentifikasikan bahwa tindak pidana lingkungan dilakukan dalam bentuk organisasional, maka orang alamiah (managers, agents, employess) dan korporasi dapat dipidana baik sendiri-sendiri maupun bersama-sama

(bipunishmentprovision);

4. Terdapat kesalahan manajemen korporasi dan terjadi apa yang dinamakan breach of $a$ statutory or regulatory provision;

5. Pertanggungjawaban badan hukum dilakukan terlepas dari apakah orang orang yang bertanggungjawab di dalam badan hukum tersebut berhasil diidentifikasikan, dituntut dan dipidana;

6. Segala sanksi pidana dan tindakan pada dasarnya dapat dikenakan pada korporasi, kecuali pidana mati dan pidana penjara. Dalam hal ini perlu dicatat bahwa Amerika Serikat mulai dikenal apa yang dinamakan corporate death penalty dan corporate imprisonment yang mengandung pengartian larangan suatu korporasi untuk berusaha di bidang-bidang usaha tertentu dan pembatasan pembatasan lain terhadap langkah-langkah korporasi dalam berusaha;

7. Penerapan sanksi pidana terhadap korporasi tidak menghapuskan kesalahan perorangan;

8. Pemidanaan terhadap korporasi hendaknya memperhatikan kedudukan korporasi untuk mengendalikan perusalaaan, melalui kebijakan pengurus atau para pengurus (corporate executive officers) yang memiliki kekuasaan untuk memutuskan (power of decision) dan keputusan tersebut telah diterima (accepred) oleh korporasi tersebut.

Dalam Undang Undang Nomor 41 Tahun 1999 jo. Undang Undang Nomor 19 Tahun 2004 tentang Kehutanan, pertanggujawaban tindak pidana korporasi terdapat pada Pasal 78 angka (14) yang dirumuskan sebagai berikut:

"Tindak pidana sebagaimana dimaksud dalam pasal 50 ayat (1), ayat (2), dan ayat (3) apabila dilakukan oleh dan atau atas nama badan hukum atau badan usaha, tuntutan dan sanksi pidananya dijatuhkan terhadap pengurusnya, baik sendiri-sendiri maupun bersama-sama, dikenakan pidana sesuai dengan ancaman pidana masing-masing ditambah dengan 1/3 (sepertiga) dari pidana yang dijatuhkan".

\section{B. Tujuan Penelitian}

Berdasarkan uraian rumusan masalah tersebut diatas, maka tujuan penelitian ini adalah, sebagai berikut:

1. Untuk mengetahui dan menganalisis unsur unsur tindak pidana dalam perusakan hutan yang dilakukan korporasi.

2. Untuk mengetahui dan menganalisis pengaturan hukum terkait tindak pidana perusakan hutan yang dilakukan korporasi.

3. Untuk mengetahui dan menganalisis pertanggungjawaban pidana terhadap korporasi atas tindak pidana perusakan hutan. 


\section{Metode Penelitian}

Jenis penelitian yang digunakan adalah jenis penelitian hukum normatif (doktrinal) yaitu penelitian dilakukan melalui studi kepustakaan (library research). Pada penelitian hukum jenis ini, hukum dikonsepkan sebagai apa yang tertulis dalam peraturan perundang-undangan (law in books) atau hukum dikonsepkan sebagai kaidah atau norma yang merupakan patokan berprilaku manusia yang dianggap pantas.

\section{Sifat Penelitian}

Sifat penelitian yang digunakan dalam penelitian ini adalah bersifat deskriptif. Penelitian bersifat deskriptif adalah bertujuan menggambarkan secara tepat sifatsifat suatu individu, keadaan, gejala atau kelompok tertentu atau untuk menentukan penyebaran suatu gejala atau untuk menentukan ada tidaknya hubungan antara suatu gejala dengan gejala lain dalam masyarakat.

2. Jenis Data dan Sumber Data

Data yang digunakan dalam penelitian ini adalah data sekunder yang bersumber dari studi kepustakaan. Data sekunder antara lain mencakup dokumen-dokumen resmi, buku-buku, hasil-hasil penelitian yang berwujud laporan, dan sebagainya. Ciri-ciri umum data sekunder adalah sebagai berikut:

1. Pada umumnya data sekunder dalam keadaan siap terbuat dan dapat dipergunakan dengan segera;

2. Baik bentuk maupun isi data sekunder, telah dibentuk dan diisi oleh peneliti-peneliti terdahulu, sehingga peneliti kemudian, tidak mempunyai pengawasan terhadap pengumpulan, pengolahan, analisis maupun konstruksi data;

3. Tidak terbatas oleh waktu dan tempat.

Jenis data sekunder yang digunakan dalam penelitian ini adalah terdiri dari bahan-bahan hukum seperti berikut:

1. Bahan hukum primer, yaitu bahan-bahan hukum yang mengikat terdiri dari: UndangUndang Republik Indonesia Nomor 5 Tahun 1967 Tentang Ketentuan-Ketentuan Pokok Kehutanan jo. Undang-Undang Republik Indonesia Nomor 41 Tahun 1999 jo. UndangUndang Republik Indonesia Nomor 19 Tahun 2004 tentang Kehutanan, dan peraturan perundang undangan lain yang brekaitan dengan penulisan karya ilmiah (skripsi).

2. Bahan hukum sekunder, yaitu bahan yang memberikan penjelasan mengenai bahan hukum primer, seperti bukubuku, hasil-hasil penelitian, jurnal-jurnal, makalah-makalah yang berkaitan dengan penelitian.

3. Bahan hukum tersier, yaitu bahan yang memberikan petunjuk maupun penjelasan terhadap bahan hukum primer dan bahan hukum sekunder, seperti kamus hukum, kamus bahasa Indonesia, kamus bahasa Inggris yang berkaitan dengan penelitian.

\section{HASIL PENELITIAN DAN PEMBAHASAN}




\section{A. TINDAK PIDANA PENGRUSAKAN HUTAN MENURUT UNDANG- UNDANG KEHUTANAN}

Pengertian Ilegal Logging dalam peraturan perundang-undangan yang ada tidak secara eksplisit didefinisikan dengan tegas. Namun terminologi illegal logging dapat dilihat dari pengertian secara harfiah yaitu dari bahas inggris. Dalam The Contemporary English Indonesia Dictionary, illegal artinya tidak sah, dilarang, atau bertentangan dengan hukum atau haram. Dalam black's Laws Dictionary illegal artinya "forbidden by law;unlawful" artinya yang dilarang menurut hukum atau tidak sah. "Log" dalam bahasa Inggris artinya menebang kayu dan membawa ketempat gergajian.

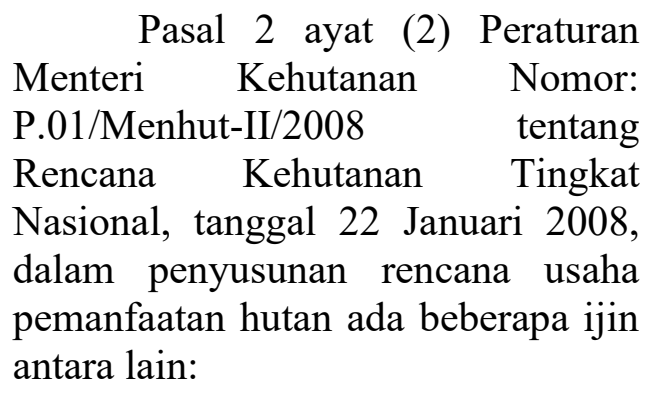

a. Izin usaha pemanfaatan pemanfaatan hasil hutan kayu dalam hutan (IUPHHK-HA);

b. Izin usaha pemanfaaatan hasil hutan kayu restorasi ekosistem dalam hutan alam (IUPPHHK$\mathrm{RE}$ );

c. Izin usaha pemanfaatan hasil hutan kayu pada hutan tanaman (IUPHHK-HT);

d. Izin usaha pemanfaatan hasil hutan kayu pada hutan tanaman rakyat (IUPHHK-HTR);

e. Izin usaha pemanfaatan jasa lingkungan (IUPJL);

f. Izin usaha pemanfaatan hasil hutan bukan kayu (IUPHHBK).
Beberapa perijinan dalam bidang kehutanan yang dapat lihat pada Undang-undang Kehutanan antara lain:

1. Izin usaha pemanfaatan kawasan Pasal 27 ayat (1) dan Pasal 29 ayat (1).

2. Izin usaha pemanfaatan jasa lingkungan Pasal 27 ayat (2) dan Pasal 29 ayat(2). 3. Izin pemungutan hasil hutan bukan kayu Pasal 27 ayat (3).

3. Izin usaha pemanfaatan hasil kayu hutan Pasal 29 ayat (4).

4. Izin pinjam pakai kawasan Pasal 38 ayat (3) dan (5).

5. Izin pertambangan Pasal 42 ayat (2), dan

6. Izin melakukan penelitian kehutanan di Indonesia kepada peneliti asing Pasal 54 ayat (2).

Terkait dalam pemanfaatan hutan lindung, ada beberapa izin yang harus dipenuhi, yakni Pasal 26 ayat (2) Undang Undang Kehutanan, bahwa pemanfaatan hutan lindung dilaksanakan melalui:

1.Perizinan usaha pemanfaatan kawasan.

2.Perizinan usaha pemanfaatan jasa lingkungan, dan

3.Izin pemungutan hasil hutan bukan kayu.

Kemudian berkaitan dengan izin pada Pasal 26 ayat (2) tersebut, maka dalam Pasal 27 Undang Undang Kehutanan dijelaskan beberapa izin dalam pemanfaatan hutan lindung dan dapat diberikan kepada siapa ijin tersebut yang meliputi:

1. Izin usaha pemanfatan sebagaimana dimaksud dalam Pasal 26 ayat (2) dapat diberikan kepada: 

a. Perorangan;
b. Koperasi.

2. Izin usaha pemanfaatan jasa lingkungan sebagaimana dalam pasal 26 ayat (2) dapat diberikan kepada:
a. Perorangan;
b. Koperasi;
c. Badan Usaha Milik Swasta Indonesia (BUMS);
d. Badan Usaha Milik Negara (BUMN) atau Badan Usaha Milik Daerah (BUMD).

3. Izin pemungutan hasil hutan bukan kayu sebagaimana dimaksud dalam pasal 26 ayat (2), dapat diberikan kepada:

a. Perorangan;

b. Koperasi.

Untuk mengetahui secara jelas perbuatan apa yang termasuk dalam kategori tindak pidana dalam bidang kehutanan maka akan dikaitkan dengan Undang Undang Kehutanan. Mengenai perbuatan apa saja yang dilarang terinci secara jelas dalam Pasal 50 ayat (3) Undang Undang Kehutanan mendefinisikan paling sedikit 13 katagori aktivitas kejahatan yang terkait dengan kehutanan yang dapat dihukum minimal selama 5 tahun dan denda antara Rp. 5 sampai dengan 10 miliar. Adapun bunyi dari Pasal 50 ayat (3) tersebut adalah sebagai berikut:

Setiap orang dilarang :

a. mengerjakan dan atau menggunakan dan atau menduduki kawasan hutan secara

b. tidak sah;

c. merambah kawasan hutan;

d. melakukan penebangan pohon dalam kawasan hutan dengan radius atau jarak sampai dengan:
1. 500 (lima ratus) meter dari tepi waduk atau danau;

2. 200 (dua ratus) meter dari tepi mata air dan kiri kanan sungai di daerah rawa;

3. 100 (seratus) meter dari kiri kanan tepi sungai;

4. 50 (lima puluh) meter dari kiri kanan tepi anak sungai;

5. 2 (dua) kali kedalaman jurang dari tepi jurang;

6. 130 (seratus tiga puluh) kali selisih pasang tertinggi dan pasang terendah dari tepi pantai.

e. membakar hutan;

f. menebang pohon atau memanen atau memungut hasil hutan di dalam hutan tanpa memiliki hak atau izin dari pejabat yang berwenang;

g. menerima, membeli atau menjual, menerima tukar, menerima titipan, menyimpan, atau memiliki hasil hutan yang diketahui atau patut diduga berasal dari kawasan hutan yang diambil atau dipungut secara tidak sah;

h. melakukan kegiatan penyelidikan umum atau eksplorasi atau eksploitasi bahan tambang di dalam kawasan hutan, tanpa izin Menteri;

i. mengangkut, menguasai, atau memiliki hasil hutan yang tidak dilengkapi bersama sama dengan surat keterangan sahnya hasil hutan;

j. menggembalakan ternak di dalam kawasan hutan yang tidak ditunjuk secara khusus untuk maksud tersebut oleh pejabat yang berwenang;

k. membawa alat-alat berat dan atau alat-alat lainnya yang lazim atau patut diduga akan 
digunakan untuk mengangkut hasil hutan di dalam kawasan hutan, tanpa izin pejabat yang berwenang;

1. membawa alat-alat yang lazim digunakan untuk menebang, memotong, atau membelah pohon di dalam kawasan hutan tanpa izin pejabat yang berwenang;

$\mathrm{m}$. membuang benda-benda yang dapat menyebabkan kebakaran dan kerusakan serta membahayakan keberadaan atau kelangsungan fungsi hutan ke dalam kawasan hutan; dan

n. mengeluarkan, membawa, dan mengangkut tumbuh-tumbuhan dan satwa liar yang tidak dilindungi undang-undang yang berasal dari kawasan hutan tanpa izin dari pejabat yang berwenang.

Terkait dengan tindak pidana terhadap hutan ini juga diatur dalam Peraturan Pemerintah Nomor 28 Tahun 1985 yakni pada Pasal 18 yang didalamnya memuat 5 ayat dalam merumuskan perbuatan apa yang dapat digolongkan sebagai tindak pidana terhadap hutan. Adapun kelima ayat tersebut pada intinya mengatur secara rinci hal-hal sebagai berikut:
a. Mengerjakan/Menduduki hutan lindung
b. Membakar hutan lindung.
c. Menegrjakan/menduduki hutan (bukan hutan lindung)
d. Salah penggunaan kawasan hutan
e. Melakukan eksplorasi dan eksploitasi hutanh tanpa persetujuan menteri

f. Eksplorasi dan eksploitasi hutan tidak sesuai dengan petunjuk menteri

g. Penggunaan alat-alat yang dapat merusak hutan

h. Penebangan pohon pelindung

i. Kebakaran hutan karena kelalian

j. Merusak/memindahkan tanda batas

k. Penggembalaan ternak dihutan

1. Mengerjakan hutan oleh yang berhak tetapi tidak sesuai dengan petunjuk menteri.

Selanjutnya Undang-Undang Kehutanan ada mengatur tentang tindak pidana dibidang kehutanan yang terkait masalah hasil hutan. Mengenai pengertian hasil hutan itu sendiri dimuat dalam Pasal 1 ayat (13) yang menyatakan: "Hasil hutan ialah benda-benda hayat, non hayati, dan turunannya, serta jasa yang bersal dari hutan". Selanjutnya menurut penjelasan pada Pasal 4 UndangUndang Kehutanan disebutkan apa saja yang termasuk dalam kategori hasil hutan. Hasil hutan tersebut dapat berupa:

a. Hasil nabati beserta turunannya seperti kayu, bambu, rotan, rumput-rumputan, jamurjamur, tanaman obat, grtah-getahan, dan lain-lain, serta bagian dari tumbuh-tumbuhan atau yang dihasilkan oleh tumbuhtumbuhan didalam hutan.

b. Hasil hewani beserta turunannya seperti satwa liar dan hasil penakarannya, satwa baru, satwa elok, dan lain-lain hewan, serta bagiannya atau yang dihasilkannya.

c. Benda-benda non hayati yang secara ekologis merupakan satu 
kesatuan ekosistem dengan benda-benda hayati penyusun hutan, antara lain berupa sumber air, udara bersih, dan lain-lain yang tidak termasuk benda-benda tambang.

d. Jasa yang diperoleh dari hutan antara lain berupa jasa wisata, jasa keindahan dan keunikan, jasa perburuan, dan lain-lain e. Hasil produksi yang langsung diperoleh dari hasil pengolahan bahan-bahan mentah yang berasal dari hutan, yang merupakan produksi primer antara lain berupa kayu bulau, kayu gergajian, kayu lapis, dan kayu pulp.Termasuk juga benda-benda tambang yang berada dihutan juga dikuasai oleh negara.

Dalam Undang Undang Kehutanan Nomor 41 Tahun 1999 telah diatur 3 (tiga) jenis sanksi yang dapat diterapkan kepada pelaku yang melakukan tindak pidana atau perbuatan melawan hukum di bidang Kehutanan. Ketiga jenis sanksi tersebut antara lain:

a. Sanksi Administratif (mulai dari Pasal 80 ayat (2) Undang Undang Nomor 41 Tahun 1999;

b. Sanksi Pidana (mulai dari Pasal 79 Undang Undang Nomor 41 Tahun 1999); dan

c. Tanggung jawab Perdata dan ganti rugi (Pasal 80 Ayat (1) Undang Undang Nomor 41 Tahun 1999).

Berhubung dalam hal ini lebih mengkaji pada sanksi pidana terhadap perbuatan pidana pengrusakan hutan, maka penulis lebih memaparkan dan menjelaskan tentang sanksi pidana saja. Sanksi atau hukuman pidana atas kejahatan (tindakan pidana) pengrusakan hutan sebelumnya dalam Undang Undang Nomor 5 Tahun 1967 tentang pokok-pokok kehutanan tidak ada diatur, sehingga tidak ada sanksi pidana yang dapat diterapkan kepada para pelaku yang melanggar ketentuan yang berkitan dengan kehutanan. Untungnya setelah muncul peraturan baru menyangkut hutan dan kehutanan, yakni Undang Undang Nomor 41 Tahun 1999 tentang kehutanan, segala jenis sanksi pidana bagi oknum oknum atau pelaku pidana telah diatur di dalamnya, walaupun sudah mengatur sanksi pidana tapi Undang Undang Nomor 41 Tahun 1999 tentang kehutanan belum mengatur kelangsungan perizinan atau perjanjian pertambangan yang telah ada sebelum berlakunya Undangundang tersebut, maka keluar lagi Undang-Undang Nomor 19 Tahun 2004 tentang perubahan atas Undang Undang Nomor 41 Tahun 1999 tentang kehutanan dengan ketentuan dijadikan sebagai bagian yang tidak terpisahkan dari Undang Undang Nomor 41 Tahun 1999. Artinya ketentuan dalam Undang Undang Nomor 41 Tahun 1999 tetap berlaku sampai sekarang.

Ketentuan pidana yang diatur dalam Pasal 50 dan sanksi pidananya dalam Pasal 78 Undang Undang No.41 Tahun 1999 tentang Kehutanan, merupakan salah satu dari upaya perlindungan hutan dalam rangka mempertahankan fungsi hutan secara lestari.

\section{B. PENGATURAN HUKUM TERKAIT}




\section{PIDANA PENGRUSAKAN \\ HUTAN \\ YANG \\ DILAKUKAN \\ KORPORASI}

Ketentuan umum yang memuat beberapa pengertian tidak termuat defenisi tindak pidana kehutanan.

Pasal 1 ayat (1) disebutkan pengertian kehutanan sebagai :

"sebuah sistem pengurusan yang bersangkut paut dengan hutan, kawasan hutan, dan hasil hutan yang diselenggarakan secara terpadu.

ayat (2) disebutkan bahwa :

"hutan adalah suatu kesatuan ekosistem berupa hamparan lahan berisi sumber daya alam hayati yang didominasi pepohonan dalam persekutuan alam."

Tindak pidana kehutanan adalah segala bentuk tindakan/perbuatan yang dapat dipidana/dikenakan hukuman yang berkaitan dengan pengurusan hutan, kawasan hutan dan hasil hutan. Kaitan yang dimaksud di sini tentunya dalam artian memberi dampak negatif terhadap sistem pengurusan hutan dan menyebabkan kerusakan terhadap hutan sebagai sebuah ekosistem penyangga kehidupan. Berbicara mengenai tindak pidana kehutanan sangat eratlah kajiannya dengan kerusakan hutan.

Dalam berbagai peraturan perundangan di bidang kehutanan istilah "kerusakan hutan"ini mengandung pengertian yang bersifat dualisme. Disatu sisi, perusakan hutan yang berdampak positif dan memperoleh persetujuan dari pemerintah tidak dapat dikategorikan sebagai tindakan yang melawan hukum.

Di sisi lain, perusakan hutan yang berdampak negatif (merugikan) adalah suatu tindakannya melawan hukum dan bertentangan dengan kebijaksanaan/tanpa adanya persetujuan pemerintah. Kerusakan hutan dapat menimbulkan dampak yang bersifat positif dan negatif didalam pembangunan yang berwawasan lingkungan.

Diantara sifat negatifnya digolongkan sebagai tindakan melawan hukum dan bertentangan dengan undang-undang. Berbagai faktor penyebab timbulnya kerusakan hutan diantaranya yaitu:

a. Kerusakan hutan dapat terjadi akibat perbuatan karena kesengajaan subjek hukum meliputi, manusia dan atau badan hukum.

b. Kerusakan hutan dapat terjadi akibat perbuatan karena kelalaian subjek hukum meliputi, manusia dan/atau badan hukum.

c. Kerusakan hutan dapat terjadi karena ternak dan daya-daya alam (misalnya gempa bumi,letusan gunung, banjir, dan sebagainya).

d. Kerusakan hutan dapat terjadi karena serangan hama dan penyakit pohon.

Lebih lanjut dipahami bahwa makna kerusakan hutan yang dapat digolongkan sebagai tindak pidana adalah merupakan suatu bentuk perbuatan yang dilakukan manusia 
dan/atau badan yang bertentangan dengan aturan didalam hukum perundang-undangan yang berlaku, dan tindak pidana perusakan hutan yang dilakukan subjek hukum sebelumnya telah dirumuskan didalam undang undang yang mengandung ketentuan pidana khusus.

Terkait dengan tindak pidana pengrusakan hutan erat kaitannya dengan pelanggaran yang sering terjadi dalam bidang kehutanan antara lain:

a. Masalah Ilegal logging atau lebih dikenal dengan penebangan hutan secara liar;

b. Masalah surat perizinan dimana untuk memperoleh kayu hasil hutan tersebut harus disertai dengan surat perizinan yang dikeluarkan oleh wewenang pemerintah yang bersangkutan;

c. Mengenai masalah Surat Keterangan Hasil Hutan dimana setiap kayu hasil hutan yang akan dipergunakan untuk kepentingan dari yang bersangkutan haruslah memperoleh atau memiliki surat keterangan hasil hutan yang akan dikeluarkan oleh pemerintah setempat.

Masalah Ilegal Logging atau lebih dikenal dengan penebangan hutan secara liar yang dilakukan tanpa ijin dari instansi/pejabat kehutanan, digolongkan sebagai tindakan yang melawan hukum. Termasuk, perbuatan penebangan liar dilakukan subjek hukum yang telah memperoleh ijin menebang namun melampaui batas/target yang diberikan instansi/pejabat kehutanan.

Dalam Inpres RI No. 5 tahun tentang Pemberantasan
Penebangan Kayu Ilegal (Ilegal Logging) dan Peredaran Hasil Hutan Illegal di Kawasan Ekosistem Lauser dan Taman Nasional Tanjung Putting, istilah Illegal Logging disamakan dengan istilah penebangan kayu illegal, istilah iilegal logging disinonimkan dengan penebangan kayu ilegal.. Ilegal logging identik dengan istilah "pembalakan illegal" yang digunakan oleh Forest Watch Indonesia (FWI) dan Global Forest watch (GFW) yaitu untuk menggambarkan semua praktik atau kegiatan kehutanan yang berkaitan dengan pemenenan, pengelolaan dan perdagangan kayu yang tidak sesuai dengan hukum Indonesia. Lebih lanjut FWI ilegal logging menjadi dua yaitu:

1. Yang dilakukan oleh operator sah yang melanggar ketentuanketentuan dalam ijin yang dimilikinya.

2. Melibatkan pencuri kayu, pohon-pohon ditebang oleh orang yang sama sekali tidak mempunyai hak legal untuk menebang pohon.

Gambaran illegal logging menurut pendapat ini menunjukkan adanya rangkaian suatu kegiatan yang merupakan suatu rantai yang saling terkait, mulai dari sumber atau produser kayu ilegal atau yang melakukan penebangan kayu secara ilegal hingga ke konsumen atau pengguna bahan baku kayu. Berdasarkan beberapa pengertian diatas, maka dapat disimpulakan bahwa illegal logging adalah rangkaian kegiatan penebangan dan pengangkutan kayu ketempat pengelolaan hinnga kegiatan ekspor kayu yang tidak mempunyai ijin dari pihak yang berwenang sehingga tidak 
sah atau bertentangan dengan aturan hukum yang berlaku.

Selanjutnya terkait masalah Surat Perizinan Pemanfaatan hutan dan penggunaan kawasan hutan, dalam Pasal 26 ayat (2) Undang Undang Kehutanan disebutkan bahwa Pemanfaatan hutan lindung dilaksanakan melalui pemberian izin usaha pemanfaatan kawasan, izin usaha pemanfaatan jasa lingkungan, dan izin pemungutan hasil hutan bukan kayu. Pemberian izin ini di atur juga dalam Pasal 33 Peraturan Pemerintah (PP) Nomor 34 Tahun 2002 jo Pasal 19 PP Nomor 6 Tahun 2007 jo PP Nomor 3 Tahun 2008 tentang Tata Hutan dan Penyusunan Rencana Pengelolaan Hutan Serta Pemanfaan Hutan, dinyatakan bahwa dalam setiap kegiatan pemanfaatan hutan yang dilakukan sebagaimana dimaksud dalam Pasal 17 ayat (2), wajib disertai dengan izin pemanfaatan hutan yang meliputi :

a. IUPK (Izin Usaha Pemanfaatan Kawasan)

b. IUPJL ( Izin Usaha Pemnafaatan Jasa Lingkungan)

c. IUPHHK ( Izin Usaha Pemanfaatan Hasil Hutan Kayu)

d. IPHHK ( Izin Pemungutan Hasil Hutan Kayu) dan

e. IPHHBK ( Izin Pemungutan Hasil Hutan Bukan Kayu).

\section{PERTANGGUNGJAWBA AN KORPORASI TERKAIT DENGAN TINDAK PIDANA PENGRUSAKAN HUTAN}

Menurut Muladi, hukum pidana modern yang bercirikan orientasi pada perbuatan dan pelaku (daad dader straafrecht), stelsel sanksinya tidak hanya meliputi pidana (straft, punishment) yang bersifat penderitaan, tetapi juga tindakan tata tertib (maatregel, treatment) yang secara relatif lebih bermuatan pendidikan.

Dengan adanya sistem dua jalur ini (double track system), maka membuka peluang bagi difungsikannya sanksi sanksi yang bersifat retributif dan teleogis secara seimbang dan proporsional, yang artinya bahwa tujuan pemidanaan yang bersifat plural dapat tercapai, yakni pencegahan (umum dan khusus), perlindungan masyarakat, memelihara solidaritas masyarakat dan pengimbalan atau perimbangan.

\section{Berbicara} tentang pertanggungjawaban pidana, maka tidak dapat dilepaskan dengan tindak pidana. Walaupun didalam pengertian tindak pidana tidak termasuk masalah pertanggungjawaban pidana. Tindak pidana hanya menunjuk kepada dilarangnya suatu perbuatan.

Kata pertanggungjawaban itu berasal dari kata bertanggungjawab, yaitu menurut Koesnadi Hardjasoemantri, bahwa kesalahan pertanggungjawaban dan pidana merupakan ungkapan yang terdengar dan digunakan dalam percakapan sehari-hari baik moral, agama, dan hukum.

Bertanggungjawab atas suatu tindak pidana berarti bahwa yang bersangkutan secara sah dapat dikenai pidana karena tindakan yang telah dilakukannya itu. Suatu tindak pidana dapat dikenakan saksi secara sah apabila untuk tindakan tersebut sudah ada aturannya dalam suatu sistem hubungan tersebut dan sisitem hukum hukum itu berlaku atas tindaklan yang dilakukan itu. Dengan perkataan lain, tindakan itu tidak dibenarkan oleh 
sistem tersebut. Inilah konsep dasrnya.

Hukum bertujuan untuk mencapai keadilan dan keadilan lazim diartikan kesamaan. Dalam penggunaan saksi pidana sebagai salah satu sarana sanksi sosial dalam segala keterbatasan, Muladi mengatakan bahwa syarat-syarat penggunaan saksi pidana secara optimal harus mencakup hal-hal:

1. Perbuatan yang dilarang tersebut menurut sebagian besar anggota masyarakat secara menyolok dianggap membahayakan masyarakat, dianggap penting oleh masyarakat.

2. Penerapan asaksi pidana terhadap perbuatan yang dilarang, konsisten dengan tujuantujuan pemidanaan.

3. Pemberantasan terhadap perbuatan tersebut, tidak akan menghalangi atau merintangi perilaku masyarakat yang diinginkan.

4. Perilaku tersebut dapat dipahami melalui cara yang tidak berat sebelah dan tidak bersifat diskriminatif.

5. Pengaturannya melalui proses hukum pidana, tidak akan memberikan kesan memperberat, baik secara kualitatif maupun secara kuantitatif.

6. Tidak ada pilaihan-pilihan yang beralaskan dari saksi pidana tersebut, untuk menghadapi perilaku tersebut.

Prinsip pertanggungjawaban korporasi (corporate liability) di Indonesia tidak diatur dalam hukum pidana umum, melainkan tersebar dalam hukum pidana khusus (tidak dikenalnya prinsip pertanggungjawaban korporasi dalam konotasi biologis yang alami (natuurlijke persoon).

Berkaitan dengan hukum pidana, ada beberapa pertanyaan yang menyangkut pertanggungjawaban pidana korporasi, yaitu:

a. Apakah suatu korporasi dapat menjadi pelaku tindak pidana mengingat korporasi tidak dapat bertindak sendiri kecuali melalui pengurus atau pegawainya da juga korporasi tidak memiliki kalbu.

b. Dalam hal bagaimana perbuatan yang dilakukan oleh personel korporasi itu pertanggungjawaban pidanaya dapat dibebankan hanya kepada korporasi;Atau dengan kata lain, dalam hal bagaimana pertanggungjawaban itu dapat dibebankan kepada personel korporasi itu. Atau dengan kata lain pula, dalam hal bagaimana pertanggungjawaban itu dapat dibebankan baik kepada personel korporasi itu maupun kepada korporasi yang bersangkutan.

2. Doktrin atau ajaran, atau teori, atau prinsip apa yang dapat dijadikan landasan pembenar untuk dapat membebankan pertanggungjawaban pidana kepada korporasi.

3. Apa bentuk sanksi pidana yang dapat dijatuhkan kepada korporasi.

J. C. Coffee Jr. dalam bukunya yang ditulis tahun 1981 sebagaimana dikutip oleh Frank dan Lynch mengemukakan bahwa pertanggungjawaban pidana korporasi (corporate criminal responsibility) telah menjadi suatu 
issue yang makin menarik perhatian akademisi selama bertahun-tahun. Masalah pertanggungjawaban pidana dari suatu korporasi telah menjadi perdebatan yang panjang sejak ratusan tahun yang lampau dan ternyata sampai dengan sekarang belum juga usai.

Membicarakan masalah korporasi/badan hukum sebagai pelaku tindak pidana Mardjono Reksodiputro, menyatakan pula bahwa, cara berpikir dalam hukum perdata dapat diambil alih kedalam hukum pidana. Menurut beliau pada mulanya dalam hukum perdata juga terjadi perbedaan pendapat apakah apakah suatu badan hukum dapat melakukan perbuatan melawan hukum (onrechtmatig hendelen). Namun, melalui asas kepatutan (doelmatigheid) dan keadilan (belijkneid) sebagai dasar utama, maka ilmu hukum perdata menerima bahwa suatu badan hukum harus dapat dianggap bersalah merupakan perbuatan melawan hukum, lebihlebih dalam lalu lintas perekonomian. Ajaran ini mendasarkan diri pada pemikiran bahwa apa yang dilakukan oleh pengurus harus dapat dipertanggungjawabkan kepada badan hukum, karena pengurus dalam bertindak tidak hanya melakukannya atas hak atau kewenangan sendiri, tetapi atas hak atau kewenangan badan hukum yang bersangkutan. ${ }^{1}$ Dengan demikian, maka badan hukum juga tidak dapat melpaskan diri dari kesalahan yang dilakukan oleh pengurus. Kesengajaan atau kelalaian dari pengurus harus dianggap sebagai kesengajaan dan

\footnotetext{
Dwidja Priyatno, Kebijakan Legalisasi Ytentang Sistem Pertanggungjawaban Pidana Korporasi Di
}

kelalian dari badan hukum sendiri.

$$
\text { Menurut R.Ali Rido }
$$
pertanggungjawaban pidana badan hukum itu ada, jika organ itu bertindak sedemikian dalam batasbatas suasana formal dari wewenangnya, tetapi organ dalam menyelenggarakan tugasnya yang mengikat badan hukum, organ dapat melakukan kesalahan-kesalahan pribadi yang merugikan badan hukum dan merupakan perbuatan melawan hukum yang mewajibkan mereka untuk mengganti kerugian secara pribadi pula. Jadi, organ yang merlakukan perbuatan itu masih dalam batas-batas wewenangnya, disamping pertanggungjawaban badan hukum, orang secara pribadi mungkin saja harus bertanggungjawab sendiri atas perbuatan melanggar hukum.

Menurut Baarda Nawawi Arief, pakar ilmu pidana, dikatakan bahwa terdapat pertimbangan dalam pemberian sanksi pidana kepada seseorang ataupun korporasi, diantaranya :

a. Penetapan sanksi dalam suatu perundang undangan pidana bukanlah sekedar masalah teknis perundang undangan semata, meliankan ia merupakan bagian tak terpisahkan dari subtansi atau materi perundang undangan itu sendiri. Artinya, masalah penalisasi, depenalisasi, kriminalisasi dan dekriminalisasi harus dipamahi secara komprehensif dengan segala aspek persoalan substansi materi perundang

Indonesia, Utomo, Bandung: 2004, hlm.75. 
undangan terhadap kebijakan legislasi. Persoalan ini perlu mendapat perhatian yang serius mengingat berbagai keterbatasan dan kemmapuan hukum pidana dalam menganggulangi kejahatan. Apalagi sering terdapat kencederungan dalam produk kebijakanlegislasi bahwa hukum pidana hampir selalu digunakan untuk menakuti atau mengamankan bermacam macam kejahatan yang mungkin tumbul diberbagai bidang.

b. Sebagai salah satu masalah sentral dalam politik kriminal, sanksi hukum pidana seharusnya dilakukan melalui pendekatan rasional, karena jika tidak, akan menimbulkan "The Crisis Of Over Criminal Law " (krisis kemampuan batas dari hukum pidana). Pentingnya pendekatan rasional ini telah banyak dikemukakan oleh para ahli hukum pidana dan kriminologi, antara lain : GP. Hoefnagels, Karl. O. Christiansen, J. Andenaes, Mc. Grath WT dan W. Clifford.

c. Masalah kebijakan menetapkan jenis sanksi dalam hukum pidana tidak terlepas dari masalah penetapan tujuan yang ingin dicapai dalam pemidanaan. Dengan kata lain, perumusan tujuan pemidanaan diarahkan untuk dapat membedakan sekaligus mengukur sejauh mana jenis sanksi, baik yang berupa "pidana" maupun "tindakan" yang telah ditetapkan pada tahap kebijakan legislasi itu dapat mencapai tujuan secara efektif. Meskipun sanksi untuk setiap bentuk kejahatan berbeda beda, namun jelas semua penetapan sanksi dalam hukum pidana harus tetap berorintasi pada tujuan pemidanaan itu sendiri.

Dalam keseluruhannya perbuatan organ badan hukum dapat dibagi dalam beberapa kategori, yaitu $:^{2}$

1. Perbuatan orang yang dilakukan dalam batas-batas wewenangnya, badan hukum terkait dan bertanggungjawab.

2. Perbuatan organ diluar wewenangnya tetapi kemudian disahkan oleh organ yang lebih tinggi atau perbuatan itu menguntungkan badan hukum. Dalam hal ini badan hukum terikat.

3. Perbuatan organ diluar wewenangnya, dengan pihak ketiga beritikad baik yang berakibat merugikan,badan hukum tidak terikat. Mereka secara pribadi bertanggungjawab tanggung menanggung dan sepenuhnya terhadap pihak ketiga. Tindakan organ yang merupakan perbuatanmelanggar hukum dalam batas-batas wewenangnya, badan hukum terikat dan bertanggungjawab.

4. Tindakan organ yang merupakan perbuatanmelanggar hukum diluar wewenangnya, badan hukum tidak terikat. Organ secara pribadi bertanggungjawab tanggung

${ }^{2} \mathrm{Ibid}, \mathrm{hlm} .78$ 
menanggung dan sepenuhnya terhadap pihak ketiga.

Tindakan organ yang merupakan perbuatan melanggar hukum dalam batasbatas wewenangnya, tetapi ada kesalahan pribadi dari organ, badan hukum tetap terikat. Namun disamping pertanggungjawaban badan hukum mereka secar pribadi bertanggungjawab pula. Badan hukum yang telah membayar ganti kerugian kepada pihak ketiga,berhak menuntut kembali kepada organ secra pribadi.

5. Perbuatan organ dalam batasbatas wewenagngnya yang bertindak lalai (melalaikan kewajiban) atau kurang hatihati yang menimbulakan kerugian bagi badan hukum, badan hukum tetap terikat. Disamping badan hukum. ada pertanggungjawaban pribadi.

Sehubungan dengan korporasi yang dijatuhi hukuman, ternyata dalam praktik belum ada putusan pengadilan atau yirisprudensinya. Akan tetapi mengenai kedudukan badan hukum/korporasi sebagai subjek hukum pidana, telah terdapat suatu putusan Mahkamah Agung Republik Indonesia tertanggal 1 Maret 1969, Nomor 136/Kr/1996 dalam perkara PT. Kosmo dan PT. Sinar Sahara, yang menyatakan, "Suatu badan hukum tidak dapat disita". Pandangan MA tersebut menurut Setiyono tepat sekali, sebab yang dapat disita adalah barang atau benda, akan tetapi merupakan "subejk hukum". Putusan MA itu

${ }^{3}$ H. Setiyono, Kejahatan Korporasi, menbegaskan bahawa Badan Hukum Korporasi merupakan subjek hukum dalam hukum pidana. Dengan putusan MA tersebut berarti ada pengakuan yuridis bahwa korporasi sebagi subjek hukum pidana.Walaupun demikian, pengertian korporasi sebagai subjek tindak pidana tidak sebatas pengakuan yuridis. Perbedaan subjek tindak pidana dibedakan antara yang melakukan tindak pidana (pembuat), dan yang bertanggungtjawab. Oleh karena itu pengaturan korporasi sebagai subjek tindak pidana tergantung peda cara atau sistem perumusan pertanggungjawaban pidana yang akan digunakan. ${ }^{3}$

Meneganai masalah penahanan terhadap pelaku tindak pidana kehutanan ini hanya dapat dikenakan terhadap tersangka atau terdakwa yang melakukan tindak pidana dan atau percobaan maupun pemberian bantuan dalam tindak pidana yang diancam dengan pidana penjara lima tahun atau lebih (Pasal 21 ayat (4) KUHAP). Untuk itu perlu diketahui apa saja dari tindak pidana bidang kehutanan dan konservasi yang masuk dalam kategori dimaksud.

Daftar Tindak Pidana dalam Undang-Undang No. 41 tahun 1999 tentang Kehutanan yang pelakunya dapat ditahan yaitu:

a. Dengan Sengaja melakukan penambangan dengan pola pertambangan terbuka (Pasal 38 ayat (4), diancam dengan pidana penjara paling lama 10 (sepuluh) tahun dan denda paling banyak Rp. 
5.000.000.000,00 (lima milyar rupiah). (Pasal 78 ayat (6));

b. Dengan sengaja merusak prasarana dan sarana perlindungan hutan (Pasal 50 (1)), diancam diancam dengan pidana penjara paling lama 10 (sepuluh) tahun dan denda paling banyak $\mathrm{Rp}$ 5.000.000.000,00 (lima milyar rupiah) (Pasal 78 (1));

c. Dengan sengaja melakukan kegiatan yang menimbulkan kerusakan hutan yang dilakukan oleh Setiap orang yang diberikan izin usaha pemanfaatan kawasan, izin usaha pemanfaatan jasa lingkungan, izin usaha pemanfaatan hasil hutan kayu dan bukan kayu, serta izin pemungutan hasil hutan kayu dan bukan kayu (Pasal 50 ayat (2)), diancam diancam dengan pidana penjara paling lama 10 (sepuluh) tahun dan denda paling banyak $\mathrm{Rp}$ 5.000.000.000,00 (lima milyar rupiah) (Pasal 78 (1));

d. Dengan sengaja mengerjakan dan atau menggunakan dan atau menduduki kawasan hutan secara tidak sah; (Pasal 50 (3) huruf a), diancam diancam dengan pidana penjara paling lama 10 (sepuluh) tahun dan denda paling banyak Rp 5.000.000.000,00 (lima milyar rupiah) (Pasal 78 (2));

e. Dengan sengaja merambah kawasan hutan (Pasal 50 (3) huruf $b$ ), diancam diancam dengan pidana penjara paling lama 10 (sepuluh) tahun dan denda paling banyak Rp5.000.000.000,00 (lima milyar rupiah) (Pasal 78 (2)); f. Dengan sengaja melakukan penebangan pohon dalam kawasan hutan dengan radius atau jarak sampai dengan:500 (lima ratus) meter dari tepi waduk atau danau; 200 (dua ratus) meter dari tepi mata air dan kiri kanan sungai di daerah rawa;100 (seratus) meter dari kiri kanan tepi sungai;50 (lima puluh) meter dari kiri kanan tepi anak sungai;2 (dua) kali kedalaman jurang dari tepi jurang;130 (seratus tiga puluh) kali selisih pasang tertinggi dan pasang terendah dari tepi pantai(Pasal 50 (3) huruf c), diancam diancam dengan pidana penjara paling lama 10 (sepuluh) tahun dan denda paling banyak Rp5.000.000.000,00 (lima milyar rupiah) (Pasal 78 (2));

g. Dengan Sengaja membakar Hutan (Pasal 50 (3) huruf d) diancam dengan pidana penjara paling lama 15 (lima belas) tahun dan denda paling banyak Rp. 5.000.000.000,00 (lima milyar rupiah). (Pasal 78 ayat (3));

h. Karena kelalaiannya membakar Hutan (Pasal 50 (3) huruf d), diancam dengan pidana penjara paling lama 5 (lima) tahun dan denda paling banyak Rp. 1.500.000.000,00 (satu milyar lima ratus juta rupiah). (Pasal 78 ayat (4));

i. Dengan Sengaja menebang pohon atau memanen atau memungut hasil hutan di dalam hutan tanpa memiliki hak atau izin dari pejabat yang berwenang; (Pasal 50 (3) huruf e), diancam dengan pidana penjara paling lama 10 (sepuluh) tahun dan denda 
paling banyak Rp. 5.000.000.000,00 (lima milyar rupiah). (Pasal 78 ayat (5))

j. Dengan Sengaja menerima, membeli atau menjual, menerima tukar, menerima titipan, menyimpan, atau memiliki hasil hutan yang diketahui atau patut diduga berasal dari kawasan hutan yang diambil atau dipungut secara tidak sah; (Pasal 50 (3) huruf f), diancam dengan pidana penjara paling lama 10 (sepuluh) tahun dan denda paling banyak Rp. 5.000.000.000,00 (lima milyar rupiah). (Pasal 78 ayat (5));

k. Dengan Sengaja melakukan kegiatan penyelidikan umum atau eksplorasi atau eksploitasi bahan tambang di dalam kawasan hutan, tanpa izin Menteri; (Pasal 50 (3) huruf g), diancam dengan pidana penjara paling lama 10 (sepuluh) tahun dan denda paling banyak $\mathrm{Rp}$. 5.000.000.000,00 (lima milyar rupiah). (Pasal 78 ayat (6));

1. Dengan sengaja mengangkut, menguasai, atau memiliki hasil hutan yang tidak dilengkapi bersama-sama dengan surat keterangan sahnya hasil hutan; (Pasal 50 (3) huruf H), diancam dengan pidana penjara paling lama 5 (lima) tahun dan denda paling banyak Rp. 10.000.000.000,00 (sepuluh milyar rupiah). (Pasal 78 ayat (7);

m. Dengan Sengaja membawa alat-alat berat dan atau alat-alat lainnya yang lazim atau patut

4 Sutan Remy Sjahdeini, Pertanggungjawaban Pidana Korporasi, Grafiti Pers, Jakarta: 2006, hlm.78. diduga akan digunakan untuk mengangkut hasil hutan di dalam kawasan hutan, tanpa izin pejabat yang berwenang; (Pasal 50 (3) huruf j) diancam dengan pidana penjara paling lama 5 (lima) tahun dan denda paling banyak Rp. 5.000.000.000,00 (lima milyar rupiah). (Pasal 78 ayat (9))

Konsep pertanggungjawaban pidana korporasi ini dikenal adanya beberapa asas utama yang menjadi dasar teori atau falsafah pembenaran dalam dibebankannya pertanggungjawaban pidana pada korporasi yaitu: Doktrin Strict Liability dan Doktrin Vicarious Liability.

\section{Pertanggungjawaban Mutlak (Strict Liability) \\ Istilah dalam bahasa}

Indonesia oleh Sutan Remy Sjahdeini disebut pertanggungjawaban mutlak. ${ }^{4}$ Salah satu pemecahan praktis bagi masalah pembebanan pertanggungjawaban pidana yang dilakukan oleh seseorang yang bekerja dilingkungan suatu korporasi kepada korporasi tempat seseorang bekerja adalah dengan menerapkan doktrine of strict of liability, pertanggungjawaban pidana dapat dibebenkan kepada pelaku tindak pidana yang bersangkutan dengan tidak perlu dibuktikan adanya kesalahan (kesengajaan atau kelalaian) pada pelakunya. Oleh karena menurut ajaran strict liability pertanggungjawaban pidana bagi pelakunya tidak dipermasalahkan, 
maka strict liability disebut juga absolute liability.

Menurut sejarahnya, prinsip tanggungjawab yang didasarkan adanya unsur kesalahan pada mulanya dikenal dalam kebudayaan kuno dari Babylonia. Dalam bentuknya yang lebih modern, prinsip ini dikenal dalam tahap awal dari hukum Romawi (abad kedua sebelum Masehi) termasuk didalamnya doktrin didalamnya mengnai "culpa" dalam Lex Aquila menentukan bahwa kerugian sebagi kesalahan seseorang baik disengaja atau tidak, secra hukum harus dibeeri santunan. Prinsip ini kemudian menjadi hukum Romawi Modern seperti terdapat dalam Psala 1382 Code Napoleon 1804 yang berbunyi : 5

"Any act whatever done by man which causus demage to another obliges him by whose fault the damage was caused to repair it".

Dalam hukum pidana berlaku asas: "actus non facit reum, nisi mens sit rea" atau "tiada pidana tanpa kesalahan", yaitu yang dikenal dengan sebagai doktrine of mens rea. Dalam perkembangan hukum pidana yang terjadi belakangan dikenal pula tindak pidana yang pertanggungjawaban pidananya dapat dibebankan kepada pelakunya sekalipun pelakunya tidak memili mens rea yang disyaratkan. Cukuplah apabila dibuktikan bahawa pelaku tindak pidana telah melakukan perbuatan ynag dilarang oleh

$\begin{array}{rrr}5 & \text { Dwidja Priyatno, Kebijakan } \\ \text { Legalisasi } & \text { Tentang } & \text { Sistem } \\ \text { Pertanggungjawaban Pidana } & \text { Korporasi di } \\ \text { Indonesia, Utomo, Bandung: 2004, hlm.107. }\end{array}$

ketentuan pidana atau atau tidak melakukan perbuatan yang diwajibkan oleh ketentuan pidana. Tindak-tindak pidana yang demikian itu disebut offences of strict liability atau sering dikenal juga sebagai offence of absolute probibition.

Tentang masalah prinsip tanggung jawab mutlak ini $\mathrm{E}$. Sefullah Wiradipradja, menyatakan $:^{6}$

Prinsip tanggung jawab mutlak (no-fault liability or liability with out fault) didalam kepustakaan biasanya dikenal dengan ungkapan "absolute liability". Dengan prinsip tanggungjawab mutlak dimaksudkan tanggungjawab tanpa keharusan untuk membuktikan adanya kesalahan. Atau dengan perkataan lain,suati prinsip tanggung jawab yang memandang :kesalahan" sebagai suatu yang tidak relevan untuk dipermasalahkan apakah pada kenyataannya ada atau tidak.

\section{Barda Nawawi Arief menayatakan bahwa seiring dipersoalkan apakah strict liability itu sama dengan absolute liability. Mengenai hal ini ada dua pendapat: ${ }^{7}$}

1. Mengatakan bahwa strict liability meupakan absolute liability. Alasan atau dasar pemikirannya ialah bahwa dalam perkara strict liability seseorang yang telah melakukan perbuatan yang

${ }^{6}$ Ibid, hlm. 65.

7 Barda Nawawai Arief, Perbandingan Hukum Pidana, Rajawali Press, Jakarta: 1990, hlm. 31. 
terlarang (actus reus) sebagaimana yang dirumuskan dalam undang-undang sudah dapatv dipidana tanpa harus mempersoalkan apakah sipelaku mempunyai kesalahan(mens rea) atau tidak. Jadi seseorang yang telah melakukan tindak pidana menurut rumusan undangundang harus/mutlak dapat dipidana.

2. Menyatakan bahwa strict liability bukan absolute liability, artinya orang yang telah melakukan perbuatan terlarang menurut undangundang tidak harus atau belum tentu dipidana.

2. Pertanggungjawaban Pengganti (Vicarious Liability)

$\begin{array}{rrr}\text { Ajaran } & \text { kedua untuk } \\ \text { memberikan pembenaran bagi }\end{array}$ pembebaban pertanggungjawaban pidana kepada korporasi adalah doctrine of vicariouas lability. Doktrin atau ajaran "vicarious liability" adalah pembebanan pertanggungjawaban pidana dan tindak pidana yang dilakuakn.

Doktrin ini juga dikenal dengan sisitem peretanggungjawaban pengganti dimana pertanggungjawaban sesorang tanpa kesalahan pribadi, bertanggungjawab atas tinadakan orang lain (a vicarious laiability is one whwre is person, though without personal fault, is more liable for the conduct of another). Vicarious liability menurut Barda Nawawi Arief, diartikan "pertanggungjawaban hukum seseorang atas perbuatan salah yang dilakukan oleh orang lain" (the legal responsibility of one personfor the wrongful acts of another). ${ }^{8}$ Atau sering disingkat

"pertanggungjawaban pengganti."

Pertanggungjawaban

pengganti (vicarious liability), dimana seseorang dimungkinkan harus bertanggung jawab atas perbuatan orang lain. Apabila teori ini diterapkan pada korporasi, berarti korporasi dimungkinkan harus bertangggung jawab atas perbuatan perbuatan yang dilakukan oleh para pegawainya, kuasanya, atau mandatarisnya, atau siapapun yang bertanggung jawab kepada korporasi tersebut. Doktrin ini, yang semula dikembangkan berkaitan dengan konteks pertanggungjawaban melawan hukum (tortious liability) dalam hukum perdata, dengan raguragu telah diambil alih kedalam hukum pidana terutama apabila tindak pidana tersebut adalah jenis tindak pidana yang merupakan absolute liability offences (strict liabilty), yaitu tindak pidana yang tidak mensyaratkan adanya mens rea bagi pemidanaan nya. Doktrin pertanggung jawaban vicarious sering kali dikeritik oleh mereka yang berpendirian bahwa doktrin ini bertentangan dengan ketentuan moral yang berlaku dalam sistem keadilaan (Justice system), yang didasarkan pada pemidanaan (punishment) atas kesalahan manusia (individual fault) untuk mempertanggung jawabkan seseorang karna telah melakukan perbuatan tertentu (yang dilarang oleh hukum) atau tidak melakukan perbuatan tertentu (yang diwajibkan oleh hukum). Teori ini secara serius dianggap menyimpang dari doktrin mens rea karena teori berpendirian bahwa kesalahan manusia secara otomatis begitu saja diatributkan

${ }^{8}$ Ibid, hlm. 40. 
kepada pihak lain yang tidak melakukan kesalahan apapun. ${ }^{9}$

Selanjutnya seseorang dapat dipertanggungjawabkan atas perbuatan orang lain adalah dalam hal- hal sebagai berikut: ${ }^{10}$

a. Ketentuan umum yang berlaku menurut common law ialah, bahwa seseorang tidak dapat dipertanggungjawabkan secara vicorious untuk tindak pidana yang dilakukan oleh pelayan/buruhnya. Jadi dalam hal ini tetap berlaku prinsip mens rea. Perkecualian terhadap ketentuan hukum diatas, artinya seseorang dipertanggungjawabkan atas perbuatan salah orang lain, adalah dalam tindak pidana terhadap public nuisance (yaitu suatu perbuatan yang menyebabkan ganguan substansial terhadap penduduk atau menimbulkan bahaya terhadap kehidupan, kesehatan, dan harta benda). Dengan demikian seorang majikan (X) dipertanggungjawabkan atas public nuisance yang disebabakan oleh pelayannya (Y) seklaipun dalam melakukan perbuatannya itu $\mathrm{Y}$ tidak mematuhi petunjuk atau perintah X. Jadi, pada prinsipnaya menurut common law seseorang majikan dapat dipertanggungjawabkan atas perbuatan (tindak pidana)yang dilakukan oleh pelayannya. Namun ada perkecualiannya yaitu dalam hal publik nuisance dan juga criminal libel. Dalam hlm.87. kedua tindak pidana ini, seorang majikan bertanggungjawab atas atas perbuatan pelayan/buruhnya sekalipun secara personal dan secara tidak langsung tidak bersalah.

b. Menurut Undang-undang (statute law), vicarious liability dapat terjadi dalam hal sebagai berikut:

1. seseorang dapat dipertanggungjawabkan atas perbuatan-perbuatan yang dilakukan oleh orang lain, apabila ia telah mendelegasikan (the delegation principle).

2. seorang majikan dapat dipertanggungjawabkan atas perbuatan yang secra fisik/jasmaniah dilakukan oleh buruh/pekerjanya apabila menurut hukum perbuatan buruhnya itun dipandang sebagai perbuatan majikan (the servant's act is the master's act in law). Jadi apabila si pekerja sebagai pembuat meteril/fisik (auctor fisicus) dan majikan sebagi pembuat intelektual (auctor intellectualis).

Berkaitan dengan penerapan ajaran pertanggungjawaban vikariouis dalam rangka pembebanan pertanggungjawaban pidana pada korporasi, Eric Colvin, dalam tulisannya tahun 1999 sebagaimana dikutip oleh Clarkson dan Keating

${ }^{10}$ Dwidja Priyatno, Op cit, hlm.102. 
mengemukan "pertanggungjawaban vicarious korporasi dikritik bahawa doktrin tersebut bersifat baik underinclusive maupun overinclisive.

Dikatakan underinclisive karena pertanggungjawaban pidana dibebankan hanya melalui pertanggungjawaban pidana dari pihak lain. Sementara itu, tindak pidana menuntut adanya sutu bentuk kesalahan yang hanya terdapat pada pelaku yang merupakan orang (manusia). Apabila tidak terdapat unsur kesalahan pada orang yang bersangkutan, maka juga tidak terdapat pertanggungjawaban korporasi dengan tidak mempersoalkan tingkat kesalahan dari korporasi tersebut. Sementara itu pertanggungjawaban vikarious juga bersifat overinclisive karena apabila terdapat pertanggungjwaban seorang, maka pertanggungjawaban pidana korporasi akan mengikuti sekalipun tidak terdapat unsur kesalahan pada korporasi. Keberatan umum terhadap pertanggungjawaban vikarious dalam hukum pidana berlaku bagi korporasi sebagaimana hal itu berlaku bagi para terdakwa (yang merupakan manusia). Karakteristik korporasi tidak memisahkannya dari pencelaan dan dari konsekuensi-konsekuensi yang timbul sebagai akibat yang dilakukannya dakwaan pidana terhadap korporasi tersebut.

Berkenaan dengan pendapat Eric Colvin tersebut diatas Clarkson dan Keating menegemukakan salah satu contoh overclusiveness dari doktrin pertanggungjawaban vicarious, yaitu mungkin suatu perusahaan harus bertanggungjawab atas dilakukannya suatu tindak pidana meskipun perusahan tersebut telah memiliki kebijakan-kebijakan yang ajelas dan telah mengeluarkan intruksi-intruksi yang jelas pula untuk mencegah jangan sampai dilakukannya perbuatan-perbuatan yang melanggar hukum (wrong doing) oleh para pegawainya. Menurut Clarkson dan Keating hampir tidak dapat dibenarkan untuk membebankan tanggungjawab kepada sebuah perusahaan atas perbuatan perbuatan yang dilakukan oleh para pegawai bawahan yang melanggar peratuaran-peraturan perusahaan dan melakukan tindak pidana. ${ }^{11}$

\section{Pertanggungjawaban Deligasi (Deligation Liability)}

Pertanggugjawaban deligasi merupakan salah satu alasan pembenar untuk dapat mebebankan pertanggungjawaban pidana yang dilakukan oleh pegawai korporasi. Menurt doktrin tersebut, alasan untuk dapat membebankan pertanggungjawaban pidana kepada korporasi adalah adanya pendelegasian wewenang dari seseorang kepada orang lain untuk melaksanakan kewenangan yang dimilikinya, misalnya saja dalam hal ini pendelegasian wewenang dari seorang pemberi kerja, yang wewenang itu diperolehnya karena ia mempunyai suatu izin usaha kepada bawahannya. Pendelegasian wewenang oleh seorang pemberi kerja kepada bawahannya merupakan alasan pembenar bagi dapat dibebankannya pertanggungjawaban pidana kepada pemberi kerja itu atas perbuatan pidana yang dilakukan oleh bawahannya itu. hlm. 96.

11 Sutan Remy Sjahdeini, Op cit, 


\section{Pertanggungjawaban Identifikasi (Identification Liability)}

Doktrin ini merupakan dasar pertanggungjawaban korporasi terhadap tindak pidana. Oleh karena itu telah dikemukakan, bahwa perusahaan bertanggungjawab atas tindak pidana yang dilakukan oleh pejabat senior di dalam perusahaan sepanjang ia melakukan dalam ruang lingkup kewenangan atau dalam urusan tarnsaksi perusahaan. Perbuatan/delik dan kesalahan/sikap batin pejabat senior dipandang sebagai sikap batin dan perbuatan perusahaan. Unsur-unsur tindaka pidana dapat dikumpulkan dari perbuatan dan sikap batin dari beberapa pejabat senior. Mengutip pendapat dari Michael J.Allen mengatakan bahwa:

the corporation will only be liabel where the person identified with it was acting within the scope of this officeit will not liabel for acts which he did in his personal capacity, artinya korporasi hanya bertanggungjawab jika orang di identifikasi dengan korporasi bertindak dalam ruang lingkup jabatannya korporasi tidak akan bertanggungjawab atas perbuatan yang dilakukan oleh orang itu dalam kapsitas pribadinya.

\footnotetext{
Dalam menentukan apakah seseorang berindak sebagai perusahaan atau hanya sebagai karyawan atau agennya, harus dibedakan antara mereka yang mewakili pikiran perusahaan dan mereka yang mewakili tangannya. Perusahaan dalam banyak hal dapat disamakan dengan tubuh manusia. Perusahaan memiliki otak dan pusat
}

syaraf yang mengendalaikan apa yang dilakukannya. Ia juga memiliki tantgan yang memegang alat dan bertindak sesuai dengan arahan dari pusat syaraf itu. Beberapa orang dilingkungan perusahaan itu hanyalah karyawan dan agen yang tidak lebih dari tangan yang melakukan pekerjaanya dan tidak dapat dikatakan sikap batin atau kehendak perusahaan. Pihak lain merupaka Direktur dan Manajer yang mewakili sikap batin yang mengarahkan dan mewakili kehendak perasaan dan mengendalaikan apa yang dilakukan. Sikap batin/keadaan jiwa para manajer ini merupakan sikap batin/keadaan jiwa perusahaan dan diberlakukan demikian menurut undang-undang. Oleh karena itu dalam kasus kasus dimana undangundang mensyaratkan kesalahan seseorang dalam pertanggungjawaban dibidang kerugian/perdata, mak kesalahan manajer dipandang sebagai kesalahan perusahaan. Demikian juga dalam bidang hukum pidana, mka kesalahan para direktur dan manajer itu dipandang sebagi kiesalahan perusahan itu sendiri.

Oleh karena itu, untuk tujuantujuan hukum, pejabat senior adalah orang orang yang mengendalaikan perusahaan baik sendiri maupun bersama pejabat senior lainnya. Ia mewakili "sikap batin dan kehendak" perusahaan, dan ia dibedakan dari mereka yang "semata-mata sebagai pegawai dan agen" dari perusahaan yang harus melaksanakan petunjukpetunjuk dari pejabat senior. Pada umumnya, para pengendali 
perusahaan adalah "para direktur dan manajer". ${ }^{2}$

\section{A. Pembebanan}

Pertanggungjawaban Korporasi

Sehubungan dengan masalah pidana dan pemidanaan, apa dan bagaimana pidana dan pemidanaan yang tepat dan dapat dijatuhkan terhadap korporasi, Sudarto menyatakan bahwa dengan diterimanya korporasi sebagai sebjek hukum pidana, maka pidana yang dapat ditetapkan tetap akan mengingat sifat korporasi. Mengenai kepada siapa pembebanan pertanggungjawaban pidana korporasi ini terdapat 3 (tiga) sistem yaitu: ${ }^{13}$

\section{Pengurus korporasi sebagai pembuat dan penguruslah yang bertanggungjawab \\ Dalam hal pengurus korporasi} sebagai pembuat dan penguruslah yang bertanggung jawab, kepada pengurus korporasi dibebankan kewajiban tertentu. Kewajiban yang dibebankan itu sebenarnya adalah kewajiban dari korporasi. Pengurus yang tidak memenuhi kewajiban itu diancam dengan pidana. Sehingga dalam sistem ini terdapat alasan yang menghapuskan pidana. Sedangkan, dasar pemikirannya adalah korporasi itu sendiri tidak dapat dipertanggungjawabkan terhadap suatu pelanggaran, melainkan selalu penguruslah yang melakukan delik itu, dan, karenanya penguruslah yang diancam pidana dan dipidana.

Ketentuan yang mengatur hal

${ }^{12}$ Dwidja Priyatno, Op cit, hlm. 89.

${ }^{13}$ Resokdipuro,Pertanggungjawaba n Pidana Korporasi Dalam Tindak Pidana Korporasi, Fakultas Hukum Universitas Diponegoro, Semarang:1998, hlm. 9 tersebut di atas diatur oleh $\mathrm{KUH}$ Pidana, seperti Pasal 169 KUH Pidana, Pasal 398, dan 399 KUH Pidana.

Pasal 169 KUH Pidana berbunyi:

1) Turut serta dalam perkumpulan yang bertujuan melak kan kejahatan, atau turut serta dalam perkumpulan lainya yang dilarang oleh aturan-aturan umum, diancam dengan pidana penjara paling lama enam tahun.

2) Turut serta dalam perkumpulan yang bertujuan melakukan pelanggaran, diancam dengan pidana penjara paling lama sembilan bulan atau pidana denda paling banyak empat ribu lima ratus rupiah.

3) Terhadap pendiri atau pengurus, pidana dapat ditambah sepertiga. ${ }^{14}$

Tindak pidana dalam Pasal 169 KUH Pidana diatas, merupakan tindak pidana kejahatan terhadap ketertiban umum, yaitu turut serta dalam perkumpulan yang terlarang. Apabila dilakukan oleh pengurus atau pendiri perkumpulan/korporasi tersebut, maka ada pemberatan pemidanaan, yaitu terhadap pendiri atau pengurus suatu korporasi apabila melakukan suatu tindak pidana yaitu turut serta dalam perkumpulan yang terlarang pidananya lebih berat bila dibandingkan dengan bukan pendiri ataupun pengurusnya. Dengan demikian yang dapat

14 Roeslan Saleh, Tentang TindakTindak Pidana dan Pertanggungjawaban Pidana, BPHN, Jakarta: 1984, hlm. 50. 
dipertanggungjawabkan dan dipidana adalah orang/pengurusnya dan bukan korporasi itu sendiri.

Pasal 398 KUH Pidana berbunyi: Seseorang pengurus atau komisaris perseroan terbatas, maskapai andil Indonesia atau perkumpulan koperasi yang dinyatakan dalam keadaan pailit atau yang diperintahkan penyelesaian oleh pengadilan diancaam dengan pidana penjara paling lama satu tahun empat bulan:

1. Jika yang bersangkutan turut membantu atau mengizinkan untuk melakukan perbuatan yang bertentangan dengan anggaran dasar, sehingga oleh karena itu seluruh atau sebagian besar kerugian diderita oleh perseroan maskapai atau perkumpulan.

2. Jika yang bersangkutan dengan maksud untuk menangguhkan kepailitan atau penyelesaian perseroan, maskapai atau perkumpulan, turut membantu atau mengizinkan peminjaman uang dengan syarat-syarat yang memberatkan, padahal diketahuinya tak dapat dicegah keadaan pailit atau penyelesaiannya.

3. Jika yang bersangkutan dapat dipersalahkan tidak memenuhi kewajiban yang diterangkan dalam Pasal 6 ayat pertama Kitab Undang-Undang Hukum Dagang, dan Pasal 27 ayat pertama Ordonansi tentang Maskapai Andil Indonesia, atau bahwa buku-buku dan suratsurat yang memuat catatancatatan dan tulusan-tulisan yang disimpan menurut pasal tadi, tidak dapat diperlihatkan dalam keadaan tak diubah. $\begin{array}{ccc}\text { Pasal } & \text { tersebut } & \text { tidak } \\ \text { membebankan } & \text { tanggung jawab }\end{array}$ pidana pada korporasinya, tetapi kepada pengurus atau komisarisnya, hal serupa juga terdapat dalam ketentuan Pasal 399 KUHP, yaitu merupakan tindak pidana yang menyangkut pengurus atau komisaris perseroan terbatas dan sebagainya yang dalam keadaan pailit merugikan perseroannya.

Ketentuan dalam KUHP tersebut jelas menganut subjek dalam hukum pidana adalah orang, hal tersebut sebagaimana ditegaskan dalam ketentuan Pasal 59 KUH Pidana. Bila dihubungkan dengan tahap perkembangan korporasi, merupakan tahap pertama, yaitu pertanggungjawaban korporasi belum dikenal, karena pengaruh yang sangat kuat asas societes delinquere non potest, yaitu bahwa badan-badan hukum tidak dapat melakukan tindak pidana atau asas universitas delinquere non potest, artinya badan hukum (korporasi) tak dapat dipidana.

\section{Korporasi sebagai pembuat dan pengurus bertanggungjawab \\ Dalam hal korporasi sebagai} pembuat dan pengurus bertanggung jawab, maka ditegaskan bahwa korporasi mungkin sebagai pembuat. Pengurus ditunjuk sebagai yang bertanggung jawab yang dipandang dilakukan oleh korporasi adalah apa yang dilakukan oleh alat perlengkapan korporasi menurut wewenang berdasarkan anggaran dasarnya.

Tindak pidana yang dilakukan oleh korporasi adalah tindak pidana yang dilakukan orang tertentu sebagai pengurus dari badan hukum tersebut. Orang yang memimpin korporasi bertanggung 
jawab pidana, terlepas dari apakah ia tahu atau tidak tentang dilakukannya perbuatan itu. ${ }^{15}$

\section{Korporasi sebagai pembuat dan juga sebagai yang bertanggungjawab}

Korporasi sebagai pembuat dan juga sebagai yang bertanggung jawab motivasinya adalah dengan memerhatikan perkembangan korporasi itu sendiri, yaitu bahwa ternyata untuk beberapa delik tertentu, ditetapkannya pengurus saja sebagai yang dapat dipidana ternyata tidak cukup. Dalam delik ekonomi bukan mustahil denda yang dijatuhkan sebagai hukuman kepada pengurus dibandingkan dengan keuntungan yang telah diterima oleh korporasi dengan melakukan perbuatan itu, atau kerugian yang ditimbulkan dalam masyarakat, atau yang diderita oleh saingannya, keuntungan dan/atau kerugian itu adalah lebih besar daripada denda yang dijatuhkan sebagai pidana. Dipidananya pengurus tidak memberikan jaminan yang cukup bahwa korporasi tidak sekali lagi melakukan perbuatan yang telah dilarang oleh undang-undang itu.

Ternyata dipidananya pengurus saja tidak cukup untuk mengadakan represi terhadap delik oleh atau dengan suatu korporasi. ${ }^{16}$ Karenanya diperlukan pula untuk dimungkinkan memidana korporasi, dan pengurus atau pengurus saja. Pendapat pendapat yang menyetujui tanggung akibat pidana dari korporsi, dapat dikemukakan sebagi berikut: ${ }^{17}$

a. Tanpa tanggung akibat pidana dari korporsi, mak akan terdapat kekosongan pemidanaan jika korporasi adalah pemilik atau pemegang izin.

b. Jelas, bahwa korporasi adalah pelaku fungsional dan menerima keuntungan dari berbagai kegiatan termasuk yangt bersifat pidana.

c. Pertimbangan praktis : Tidak mudah untuk menelusuri garis perintah dalam hal terjadi kejahatan dalam korporasi; dan Pidana terhadap pengurus korporasi tidak mempengaruhi perbuatan korporasi.

d. Selaras dengan perkembangan dalam hukum perdata.

\section{Mengingat KUH Pidana} menganut sistem dua jalur (double track sistem) dalam pemidanan, dalam arti disamping pidana dapat pula dikenalkan berbagai tindakan kepada pelaku, maka sistem ini dapat pula diterapkan dalam pertanggungjawaban korporasi sebagai pelaku tindak pidana. Sesuai motif-motif kejahatan korporasi, sanksi yang bersifat ekonomis dan administratif tanpaknya lebih sesuai diterapkan dalam pertanggungjawaban korporasi sebagai pelaku tindak pidana. Dengan demikian, disamping pidana denda, korporasi dapat pula dijatuhi:

a. Pidana tambahan seperti penutupan sebagian atau seluruh perusahaan, pengumuman putusan hakim, perampasan barang-barang tidak tetap, baik yang berwujud maupun yang tidak berwujud;

\footnotetext{
${ }^{17}$ Dwidja Priyatno, Op cit, hlm. 55
}

${ }^{16} \mathrm{Ibid}, \mathrm{hlm} .52$ 
atau

b. Tindakan tata tertib penempatan perusahaan dibawah pengampuan atau pengawasan, kewajiban membayar uang jaminan dan kewajiban membayar sejumlah uang sebagai pencabutan keuntungan.

Tentang hal ini Suprapto menyatakan bahwa hukuman yang dapat dikenakan kepada perusahaan (korporasi) adalah sebagai berikut: ${ }^{18}$

a. penutupan seluruhnya atau sebagian perusahan siterhukum untuk waktu tertentu.

b. Pencabutan seluruh atau sebagian fasilitas tertentu yang telah atau dapat diperolehnya dari pemerintah oleh perusahaan selama waktu tertentu, dan

c. Penempatan perusahaan dibawah pengampuan selama waktu tertentu.

Sehubungan dengan sanksi yang dapat dikenakan terhadap korporasi Andi Hamzah menyatakan bahwa untuk sekarang ini terbuka kemungkinan menuntut pidana kepada korporasi yang merusak hutan. Begitupula pencabutan izin, lisensi, dan sebagainya oleh pemerintah daerah. Patut pula diingat bahwa korporasi itu tidak mungkin dipidana badan, oleh karena itu jika ditentukan bahwa tindak pidana tertentu dapat dilakukan oleh korporasi, maka tindak pidana itu harus diancam dengan pidana alternatif yang berupa pidana denda.

Kemudian,

Muladi

mengemukakan bahwa berkaitan dengan pertanggungjawaban pidana korporasi dengan memperhatikan dasar pengalaman pengaturan hukum positif serta pemikiran yang berkembang maupun kecenderungan internasional, maka pertanggungjawaban korporasi dalam hal tindak pidana yang merusak hutan, maka pertanggungjawaban korporasi dalam tindak pidana lingkunagn hendaknya memperhatikan hal-hal:

1) Korporasi mencakup baik badan hukum (legal entity) maupun non badan hukum seperti organisasi dan sebagainya.

2) Korporasi dapat bersifat privat (privat juridical entity) dan dapat pula bersifat publik (public entity).

3) Apabila diidentifikkasikan bahwa tindak pidana lingkungan dilakukan dalam bentuk organisasional, maka orang alami dan korporasi dapat dipidana bauk sendiri-sendiri maupun bersama sama.

4) Terdapat kesalahan manajemen korporasi

5) Pertanggungjawaban bandan hukum dilakukan terlepas dari apakah orang-orang yang bertanggungjawab di dalam badan hukum tersebut berhasil diidentifikasi, dituntut, dan dipidana.

6) Segala sanksi pidana dan tindakan pada dasarnya dapt dikenakan pada korporasi, kecuali pidana mati dan pidana penjara. Dalam hal ini perlu dicatat bahwa Amerika Serikat mulai dikenal apa yang dinamakan corporate death penalty dan corporate imprisionment yang mengandung pengertian

${ }^{18}$ H. Setiyono, Op cit, hlm. 152. 
larangan suatu korporasi untuk berusaha dibidang- bidang usaha tertentu dan pembatasanpembatasan lain terhadp langkah-langkah korporasi dalam berusaha.

7) Penerapan sanksi pidana terhadp korporasi tidak menghapus kesalahan perorangan.

8) Pemidanaan terhadap korporasi hendaknya memperhatikan kedudukan korporasi untuk mengendaliakn perusahaan, melalui kebijakan pengurus atau para pengurus (corporate executive officers) yang memiliki kekuasaan untuk memutuskan (power of decision) dan keputusan tersebut telah diterima (accepted) oleh korporasi tersebut. ${ }^{19}$

Badan hukum yang mempunyai kesalahan, harus menanggungnya dengan kekayaan, dan selanjutnya adanya pengetahuan bersama dari sebagian anggota dapat dianggap sebagai kesengajaan badan hukum itu. Kesengajaan bersyarat dan kesalahan ringan setiap orang yang bertindak untuk korporasi itu jika dikumpulkan akan dapat ,merupakan kesalahan besar dari korporasi itu sendiri. ${ }^{20}$ Sebagaimana halnya orang, badan hukum atau korporasi dapat mempunyai dasar untuk menghapuskan pidana, sebagai konsekuensi diterimanaya asas kesalahan pada korporasi. Pemahaman tentang hal ini dapat dikemukakn sebagi berikut:

19 Alvi Syahrin, Bebarapa Isi Hukum lingkungan Kepidanaan, Sofmedia, Medan: 2009, hlm. 40
1) Dalam menilai pertanggungjawaban pidana terhadap korporasi, ternyata alasan alasan penghapus kesalahan (alasan pemaaf) tetap berlaku terhadap korporasi, dengan mendasrakan pada ketiadaan semua kesalahan (afwezigheid van alle schuld).

2) Alasan-alasan pemaaf lain, seperti daya paksa (overmacht) tidak selalu bisa diambilkan dari alasan pemaaf natuurlijke persoon yang bertidak untuk dan atas nama korporasi.

3) Alasan pemaaf yang berupa ketidakmampuan

bertanggungjawab yang diatur dalam Pasal 44 KUHP dan pembelaan terpaksa (darurat) yang melampaui batas sebagiman diatur dalam Pasal 49 ayat(2) KUHP tidak bisa dimbil alih sebagai alasan pemaaf korporasi, karena kedua jenis alasan pemaaf korporasi, karena kedua jenis alasan pemaaf ini mensyaratkan keadaan jiwa tertentu, yang mutlak hanya dapat terjadi pada diri manusia. ${ }^{21}$

Berdasarkan pada apa yang telah diuraikan diatas teranglah kiranya mengenai bagaimana pertanggungjawaban korporasi terkait masalah pengrusakan hutan yang berdasarkan Undang-Undang No. 41 Tahun 1999. Dimana melalui rumusan Pasal 78 dapat diketahui siapa yang menjadi pelaku tindak pidana di bidang pengrusakan hutan, yakni "setiap orang". Setiap orang dalam ketentuan pasal ini menunjuk

${ }^{20}$ Ibid, hlm. 41.

${ }^{21}$ H. Setiyono, Op cit, hlm.159. 
pada perorangan, koperasi, badan hukum milik swasta, maupun badan hukum milik negara atau pun badan hukum milik daerah (termasuk dalam ketentun ini adalah "korporasi").

\section{Terkait Pemebebanan} pertanggungjawaban pada korporsi ini dapat dilakukan bilamana korporsi yang bersangkutam tidak mempunyai izin dalam usaha dan pemanfaatan hasil hutan, maupun terhadap korporasi yang telah memiliki izin dari pejabat yang berwenang namun dalam pelaksanaan kegiatannya menyalahi ketentuan dari perundangundangan maupun melampaui dari izin yang diberikan. Yang terpenting yang perlu diingat dalam hal ini bahwa dampak yang ingin dicapai dalam pemeberian saksi terhadap korporasi tersebut tidak hanya mempunyai finansial impact. Karena itu dapat dikemukakan bahwa pidana mati, pidana kurungan tidak dapat dijatuhkan pada korporasi. Sanksi yang dapat djatuhkan pada korporasi adalah pidana denda, pidana tambahan, tindakan tata tertib, tindakan administratif dan sanksi keperdataan berupa ganti kerugian. ${ }^{22}$

\section{KESIMPULAN}

1. Unsur unsur tindak pidana pengrusakan hutan menurut Undang undang Nomor 41 Tahun 1999 tentang Kehutanan merupakan perbuatan baik sengaja maupun karena kelalaian yang mengakibatan kerusakan terhadap hutan atau kawasan dan ekosistemnya. Namun ketentuan tersebut khusus pada kawasan suaka alam dan taman nasional, taman hutan raya dan taman wisata; dan perbuatan baik sengaja maupun karena kelalaian mengambil, menebang, memiliki, merusak, memusnahkan memelihara, mengangkut, memperniagakan dan menyelundupkan hasil hutan. Rumusan definisi kerusakan adalah terjadinya perubahan fisik, sifat fisik atau hayatinya, yang menyebabkan hutan tersebut terganggu atau tidak dapat berperan sesuai dengan fungsinya.

2. Pengaturan hukum terkait tindak pidana pengrusakan hutan yang dilakukan korporasi adalah pada Pasal 50 Undang Undang Nomor 41 Tahun 1999 tentang Kehutanan dimana dilarang: mengerjakan dan atau menggunakan dan atau menduduki kawasan hutan secara tidak sah; merambah kawasan hutan; melakukan penebangan pohon dalam kawasan hutan; membakar hutan; menebang pohon atau memanen atau memungut hasil hutan di dalam hutan tanpa memiliki hak atau izin dari pejabat yang berwenang; menerima, membeli atau menjual, menerima tukar, menerima titipan, menyimpan, atau memiliki hasil hutan yang diketahui atau patut diduga berasal dari kawasan hutan yang diambil atau dipungut secara tidak sah; melakukan kegiatan penyelidikan umum atau eksplorasi atau eksploitasi bahan tambang di dalam kawasan hutan, tanpa izin Menteri; mengangkut, menguasai, atau memiliki hasil hutan yang tidak dilengkapi bersama sama dengan surat keterangan sahnya hasil hutan; menggembalakan ternak di dalam kawasan hutan yang tidak ditunjuk secara khusus untuk maksud 
tersebut oleh pejabat yang berwenang; dan membawa alatalat berat dan atau alat-alat lainnya yang lazim atau patut diduga akan digunakan untuk mengangkut hasil hutan di dalam kawasan hutan, menebaang, memotong, membuang benda benda yang dapat menyebabkan kebakaran serta membahayakan kelangsungan fungsi hutan ke dalam kawasan hutan tanpa izin pejabat yang berwenang;

3. Pertanggungjawaban korporasi terkait dengan tindak pidana pengrusakan hutan dalam Undang Undang Nomor 41 Tahun 1999 terdapat pada Pasal 78 ayat (14) yang merumuskan bahwa Tindak pidana sebagaimana dimaksud Pasal 50 apabila dilakukan oleh dan atau atas nama badan hukum atau badan usaha, tuntutan dan sanksi pidananya dijatuhkan terhadap pengurusnya, baik sendiri-sendiri maupun bersamasama, dikenakan pidana sesuai dengan ancaman pidana masingmasing ditambah dengan 1/3 (sepertiga) dari pidana yang dijatuhkan". Tanggung jawab korporasi pada Undang-Undang Nomor 41 Tahun 1999 tentang Kehutanan, apabila tindak pidana yang dilakukan oleh dan atau atas nama badan hukum atau badan usaha, yang bertanggujawab adalah pengurusnya, baik sendirisendiri maupun bersama sama, ini maksudnya dapat ditafsirkan bahwa pengurus atas nama pribadi atau sendiri dapat diminta pertanggungjwaban atau pengurus yang melakukan secara bersamasama bisa diminta pertangggujawaban. Oleh karenanya bukan badan hukum yang bisa diminta pertanggujawaban dalam tindak pidana korporasi ini, hanya pada pengurus dari badan hukum yang bisa diminta pertanggungjwaban.

\section{DAFTAR PUSTAKA}

\section{A. Buku}

Ali, Ahmad, Menguak Tabir Hukum (Suatu Kajian Philosophis dan Sosiologis), Chandra Prtama, Jakarta: 1996.

Amiruddin dan Asikin, Zainal, Pengantar Metode Penelitian Hukum, Rajawali Pers, Jakarta: 2012.

Arief, Barda Nawawi, Tindak Pidana Perkembangan Kajian Cyber Crime di Indonesia, Raja Grafindo Persada, Jakarta: 2006.

, Beberapa Aspek Kebijakan Penegakan dan Pengembangan Hukum Pidana, Citra Aditya Bakti, Bandung: 2005.

, Bunga Rampai Hukum Pidana, Alumni, Bandung: 1992.

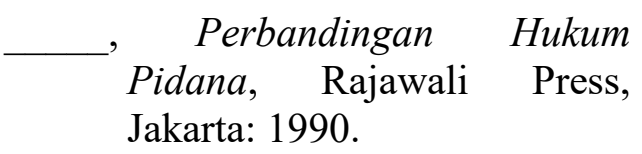

Hardjasoemantri, Koenadi, Hukum Tata Lingkungan, Gajah Mada, Jakarta: 1992.

H. S. Salim, Dasar Dasar Hukum Kehutanan, Sinar Grafika, Jakarta: 2005.

Henry Campbell, Black, Black's Law Dictionary, West Publishing Co., St. Paul, Minnessota, 1990.

Khakim, Abdul, Pengantar Hukum Kehutanan Indonesia Dalam 
Era Otonomi Daerah, Citra Aditya Bakti, Bandung: 2005.

Marpaung, Laden, Tindak Pidana Terhadap Hutan, Hasil Hutan, dan Satwa, Erlangga, Jakarta: 1995.

Moeljatno, Perbuatan Pidana dan Pertanggungjawaban Dalam Hukum Pidana, Bina Aksara, Yogyakarta: 1983.

Nurdjana, Korupsi dan Ilegal Logging Dalam Sistem Desentralisasi, Pustaka Belajar,Yokyakarta: 2005.

Pope, Strategi Memberantas Korupsi, Yayasan Obor Indonesia, Jakarta: 2003.

Prasetyo, Teguh dan Barkatullah, Abdul Halim, Politik Hukum Pidana Kajian Kebijakan Kriminalisasi dan Dekriminalisasi, Pustaka Pelajar, Yogyakarta: 2005.

Priyatno, Dwidja, Kebijakan Legalisasi Tentang Sistem Pertanggungjawaban Pidana Korporasi di Indonesia, Utomo, Bandung: 2004.

Resokdipuro, Pertanggungjawaban Pidana Korporasi Dalam Tindak Pidana Korporasi, Fakultas Hukum Universitas Diponegoro, Semarang: 1998.

Saleh, Roeslan, Perbuatan Pidana dan Pertanggung Jawaban Pidana, Aksara Baru, Jakarta: 1983.

Setiyono, H., Kejahatan Korporasi, Bayu Media, Malang: 2005.

Sholehuddin, Sistem Sanksi Dalam Hukum Pidana (Ide dasar Double Track System dan Implementasinya), Rajawali Pers, Jakarta: 2002.
Sjahdeini, Sutan Remy, Pertanggungjawaban Pidana Korporasi, Grafiti Pers, Jakrata: 2006.

Soemartono, Gatot P., Hukum Lingkungan Indonesia, Sinar Grafika, Jakarta: 1996.

Soemetro, P., dan Prastyo, Teguh, Sari Hukum Pidana, Mitra Prasaja Ofset, Yogyakarta: 2002.

Soesilo, R., KUHP Serta KomentarKomentar Lengkap Pasal Demi Pasal, Politeia, Bogor: 1988.

Soekanto, Soerjono, Pengantar Penelitian Hukum, Universitas Indonesia Press, Jakarta: 1986.

Suantoro, Aspek Pidana Dibidang Ekonomi, Ghalia Indonesia, Jakarta: 1990.

Sudarto, Kapita Selekta Hukum Pidana. Alumni, Bandung: 1986.

Sudaryono dan Surbakti, Natangsa, Buku Pegangan Kuliah Hukum Pidana. Surakarta: Fakultas Hukum Universitas Muhammadiyah Surakarta: 2005.

Sunarso, Siswanto, Hukum Pidana Lingkungan Hidup dan Strategi Penyelesaian Sengketa, Rineka Cipta, Jakarta: 2005.

Susanto, Statistik Kriminal Sebagai Konsruksi Sosial, Penyusunan, Penggunaan dan Penyebarannya: Suatu Studi Kriminologi, Semarang: 1990.

Supardjaja, Komariah Emong, Ajaran Sifat Melawan Hukum Materiel Dalam Hukum 
Pidana Indonesia, Alumni, Bandung: 2002.

Syahrin, Alvi, Bebarapa Isi Hukum lingkungan Kepidanaan, Sofmedia, Medan: 2009.

Tunggal, Hadi Setia, Himpunan Peraturan Pelaksana Undang-Undang Kehutanan, Harvindo, Jakarta: 2009.

Wiljatmo, S. Pengantar Ilmu Hukum, Lukman Opset. Yogyakarta: 1979.Sahetapy, Kejahatan Korporasi, Eresco, Bandung: 1994.

Zain, Alam Setia, Hukum Lingkungan Konservasi Hutan, Rineka Cipta, Jakarta: 1994.

\section{B. Undang-Undang}

Kitab Undang Hukum Pidana.

Undang Undang Republik Indonesia Nomor 5 Tahun 1967 Tentang Ketentuan Ketentuan Pokok Kehutanan.

Undang Undang Republik Indonesia Nomor 41 Tahun 1999 jounto Undang Undang Republik Indonesia Nomor 19 Tahun 2004 Tentang Kehutanan.

\section{Makalah}

Bawono, Bambang Tri dan Mashdurohatun, Anis, Penegakan Hukum Pidana di Bidang Illegal Logging Bagi Kelestarian Lingkungan Hidup dan Upaya Penanggulangannya, Jurnal Hukum, Vol. XXVI, No. 2. Agustus 2011.

Muladi, Prinsip-prinsip Dasar Hukum Pidana Lingkungan Dalam Kaitanrrya Dengan Undang Undang No. 23 Tahun 1997, Makalah, Seminar Kajian dan
Sosialisasi Undang-Undang No. 23 Tahun 1997, (Semarang: Fakultas Hukum Universitas Diponegoro, 1998).

Syahrin, Alvi, Pertanggungjawaban Pidana Korporasi Dalam Pencemaran dan Atau Kerusakan Lingkungan Hidup, (Medan: Pidato Pengukuhan Jabatan Guru Besar Tetap dalam llmu Hukum/Lingkungan pada Fakultas Hukum Universitas Sumatera Utara, Tanggal 20 Desember 2003).

D. Internet

http://www.wikipedia.org/wiki/Pemb alakan liar.

http://library.usu.ac.id,/ Harahap, Nurasiah, Analisis Hukum Tanggung Jawab PT Dalam Pengelolaan Lingkungan Hidup.

http://www.solusihukum.com/Rusma na, Pertanggungjawaban Korporasi Dalam Tindak Pidana Perikanan.

http:/www.blogspot.com/,email:fafa law@yahoo.com,/ Kotijah, Siti, Eksploitasi Kawasan Hutan di Indonesia Oleh Korporasi.

http://www.blogspot.com/, Suprapto, Kebijakan Hukum Pidana Dalam Bidang Kehutanan.

http://email

teguhsoedarsono@ymail.com Soedarsono, Teguh, Penegakan Hukum dan Putusan Pengadilan KasusKasus Illegal Logging. 